Research Article

\title{
Results of operation the online medical care system in high schools
}

\begin{abstract}
Introduction: Online Medicare is a method in which parts of a medical process - whether its diagnostics, monitoring or the treatment itself will be done by using online services. This system has been operated in one boys high school, one girls high school and one high school in deprived aria.
\end{abstract}

Method: At the first step the students registered for using the system. It was not mandatory and not free. They participated in estimating depression scale, anxiety scale and clinical interview by online medical care system. During this estimation, we could find the existence and severity of depression and anxiety in each one of the participants, also we could find the consequent needs of each one, such as supportive therapy in mild depression or anxiety, need to visited by psychologist in moderate cases, need to visited by psychiatrist in moderate-severe cases, need to visited by psychiatrist and psychologist in severe cases and need to perform medical lab examination tests. The lab examination tests were performed on persons specified by the system. In the lab examinations were included: serum level of vitamin D, serum level of vitamin B12, serum level of calcium, fasting blood sugar, $\mathrm{HbA} 1 \mathrm{c}$, thyroid function tests and $\mathrm{CBC}$. All of the students were solely treated by vitamins or minerals therapy and/ or treatment of medical problem (such as hypothyroidism).

Results: In girls high school: the existence and severity of depression significantly decreased $(\mathrm{P}$ value $=0.018<0.05)$, but results about anxiety was not significant. In boys high school: the existence and severity of depression significantly decreased $(\mathrm{P}$ value $=$ $0.023<0.05$ ), but results about anxiety was not significant in high school in deprived area the students did not have any problem paying for participating in the project, but they could not pay for medical lab examination tests. Thus, operation of the system was not possible in deprived area without a sponsor.

Conclusion: This online medical system was successful in creating medical and psychiatric profile without attending physician. It was successful in decreasing depression without using antidepressants, but it was not successful in decreasing anxiety.
Volume 2 Issue 3 - 2015

Mahsa Houshdar

Hooshdar Medical Technology Company, Iran

Correspondence: Mahsa Houshdar, Hooshdar Medical Technology Company, Iran - Karaj - Taleghani Ave - No 455 Second Floor, Tel 009832264770, 00989354928I32, Emailmhooshdar@gmail.com

Received:December 10,2014 | Published: March 19, 2015

\section{Introduction}

Online Medicare is a method in which parts of a medical process, whether its diagnosing, monitoring or the treatment itself, will be done by using online services. The website (www.hooshdar.com) is an effort to bring fairness in health to people across the globe using modern methods. We choose psychiatric disorder depression and anxiety to be our focus in phase one. Why we choose depression and anxiety in the first line of online Medicare?

The prevalence: The global mean prevalence for depression is about $\% 17$ in the life period. ${ }^{1}$ This is about $\% 14$ to $\% 24$ in adolescent. ${ }^{2}$ The global mean for anxiety is $\% 25$ in total. It is $\% 30.5$ in women and $\% 19.2$ in men. ${ }^{3}$

The second reason for this choice is the morbidities that can be caused by these two diseases. Depression \& anxiety can cause decrease in concentration that will reduce interest in doing homework. It can cause fatigue and drowsiness, all of which cause academic failure. ${ }^{4}$ Depression can cause antisocial behavior in adults, disobedience of rules is its consequence. ${ }^{5}$ It can cause conduct disorder in adolescents too. It can increase the chance of addiction to opium or alcohol. ${ }^{4}$ Conduct disorders can cause following problems in adolescents: aggressive behavior causing bodily harm to oneself or others, destruction of property, theft and fraud, disturbing law and order related to their age. ${ }^{6,7}$
Neither depression nor anxiety doesn't always occur spontaneously, in many cases they are created because of some other diseases, such as diabetes or hypo or hyperthyroidism. ${ }^{1}$

Thus, if we can diagnose depression \& anxiety, finally we can find the medical diseases which trigger them. Then we can use a plan for a combined treatment. By this way we can prevent many academic failure and aggressive behavior in the high schools.

\section{For finding the main diseases which should be considered}

First, I considered the 13 to 19 year old depressed or anxious patients, who were referred to my personal office for medical disorders, they showed:
i. Hypothyroidism (\%11.1)
ii. Impaired GTT (\%8.33)
iii. Reactive hypoglycemia (\%5.5)
iv. Hypocalcaemia (\%13.88)
v. Vitamin b12 deficiency (\%38.88)
vi. Poly cystic ovary $(\% 2,52)$
vii. Thalassemia $(\% 2.52)$. 
After this research we decided to search Hypothyroidism, vitamin B12 deficiency, Hypocalcaemia, diabetes, impaired fasting glucose level, hypoglycemia, and anemia in persons, who were presented for lab examination by the system. After two years we decided to change hypocalcaemia with vitamin d deficiency.

With Ministry of Education's permission, we decided to operate this system in high schools. As pilot study during three years we operated the system in one girls high school, one boys high school and one high school in a deprived aria. Participating in this program was neither mandatory nor free, thus the results cannot be generalized, but it can show the relationship between depression and anxiety with medical diseases in Iran and the effectiveness of operating the system in schools in decreasing these two problems. Results in high school in deprived area:

We can show the results by using a few tables (Table 1-3):

A. As you see: Only $\% 10$ persons from $\% 43$ persons who chosen by system for lab examinations, could pay the price of lab examination in the high school of deprived area. These pilot studies show that participating in this program in high schools in deprived areas without sponsor is not possible.

B. Results in girls high schools: The results in girls high schools show that, operating the system can reduce the rate and severity of depression significantly. Because of low participation, we cannot reach statistically significant results about anxiety. We can show the results by using a few tables (Table 4-6):
After four month we come back to the high school, and measured the severity of depression and anxiety in the participants who treated by folic acid, Fe, levothyroxine and vitamin b12. No one treated by ant anxiety or antidepressant. Results show:

a. Statistical results in anxiety scale test GAD7.

b. The $\mathrm{P}$ value is 0.1244 ( $>0.05$, Signed rank test comparing the mean versus 0 ). The lack of difference may be due to lack of statistical power, (with more subjects, we could perhaps show a significant difference)

c. Statistical results in depression scale test PHQ9.

d. The mean difference between baseline and final endpoint is -2.9 with a standard deviation of 3.96 , the $95 \%$ Confidence interval is $-4.9 ;-0.9$ and don't contains 0 , so the difference between before and after is statistically significant for this parameter. On the other hand the $\mathrm{P}$ value is $0.018(<0.05$, Signed rank test comparing the mean versus 0 ).

\section{Results in boys high schools}

e. The results in boy's high schools show that; operating the system can reduce the rate and severity of depression significantly in treated patients compared with non treated patients and semi treated patients. Although we cannot reach statistically significant results about anxiety. We can show the results by using a few tables (Table 7-9).

Table I Severity of Depression in Total Participants, and their needs according to the severity of depression in deprived high school

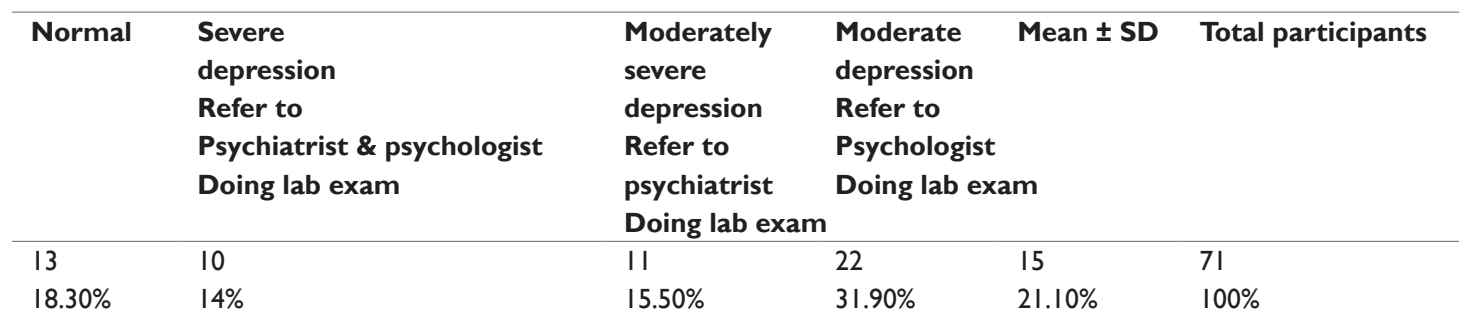

Table 2 Severity of Anxiety in Total Participants, and their needs according to the severity of Anxiety in deprived high school

\begin{tabular}{llllll}
\hline Normal & Severe & Moderately & Moderate & Mild & Total \\
& $\begin{array}{l}\text { Anxiety } \\
\text { Refer to }\end{array}$ & $\begin{array}{l}\text { Anxere } \\
\text { Anxiety }\end{array}$ & $\begin{array}{l}\text { Anxiety } \\
\text { Refer to }\end{array}$ & $\begin{array}{l}\text { Anxiety } \\
\text { Supportive }\end{array}$ & \\
& $\begin{array}{l}\text { Psychiatrist \& } \\
\text { psychologist }\end{array}$ & $\begin{array}{l}\text { Refer to } \\
\text { psychiatrist }\end{array}$ & $\begin{array}{l}\text { Psychologist } \\
\text { Doing lab }\end{array}$ & Therapy & \\
& Doing lab & Doing lab & Exam & & \\
& Exam & Exam & & & \\
& I & 8 & 21 & 29 & 71 \\
\hline 12 & $1.50 \%$ & $11 \%$ & $29.50 \%$ & $41 \%$ & $100 \%$ \\
\hline
\end{tabular}

Table 3 The rate of medical diseases in the participants who chosen by the system for lab exam

\begin{tabular}{|c|c|c|c|c|}
\hline Anemia & $\begin{array}{l}\text { Low } \\
\text { calcium } \\
\text { blood } \\
\text { level }\end{array}$ & $200<$ Vitamin bl $2<350$ & Vitamin b $\mid 2<200$ & $\begin{array}{l}\text { Total } \\
\text { participants }\end{array}$ \\
\hline I & I & 5 & I & 7 \\
\hline Hypothyroidism & $\begin{array}{l}\text { High } \\
\text { Cholesterol } \\
\text { or TG } \\
\text { blood level }\end{array}$ & $\begin{array}{l}\text { Impaired } \\
\text { fasting } \\
\text { glucose }\end{array}$ & Diabetes & $\begin{array}{l}\text { Total } \\
\text { participants }\end{array}$ \\
\hline 0 & 0 & 0 & 0 & 7 \\
\hline
\end{tabular}


Table 4 Severity of Depression in Total Participants, and their needs according to the severity

\begin{tabular}{lllll} 
Normal & $\begin{array}{l}\text { Severe } \\
\text { depression } \\
\text { Refer to } \\
\text { Psychiatrist \& psychologist Doing lab } \\
\text { exam }\end{array}$ & $\begin{array}{l}\text { Moderately } \\
\text { severe } \\
\text { depression } \\
\text { Refer to } \\
\text { psychiatrist } \\
\text { Doing lab } \\
\text { exam }\end{array}$ & $\begin{array}{l}\text { Moderate } \\
\text { depression } \\
\text { Refer to } \\
\text { Psychologist } \\
\text { Doing lab } \\
\text { Exam }\end{array}$ & $\begin{array}{l}\text { Mild } \\
\text { depression } \\
\text { Supportive } \\
\text { Therapy }\end{array}$ \\
participants \\
\hline 28
\end{tabular}

Table 5 Severity of Anxiety in Total Participants, and their needs according to the severity of Anxiety in deprived high school

\begin{tabular}{|c|c|c|c|c|c|}
\hline Normal & $\begin{array}{l}\text { Severe } \\
\text { Anxiety } \\
\text { Refer to } \\
\text { Psychiatrist \& } \\
\text { psychologist } \\
\text { Doing lab } \\
\text { exam }\end{array}$ & $\begin{array}{l}\text { Moderately } \\
\text { severe } \\
\text { Anxiety } \\
\text { Refer to } \\
\text { psychiatrist } \\
\text { Doing lab } \\
\text { exam }\end{array}$ & $\begin{array}{l}\text { Moderate } \\
\text { Anxiety } \\
\text { Refer to } \\
\text { Psychologist } \\
\text { Doing lab } \\
\text { exam }\end{array}$ & $\begin{array}{l}\text { Mild } \\
\text { Anxiety } \\
\text { Supportive } \\
\text { Therapy }\end{array}$ & $\begin{array}{l}\text { Total } \\
\text { participants }\end{array}$ \\
\hline 100 & 38 & 31 & 4 & 0 & 28 \\
\hline $100 \%$ & $38 \%$ & $31 \%$ & $4 \%$ & $0 \%$ & $28 \%$ \\
\hline
\end{tabular}

Table 6 The rate of medical diseases in the persons, chosen by the system for lab exam

\begin{tabular}{|c|c|c|c|c|c|}
\hline $\begin{array}{l}\text { Total } \\
\text { participants }\end{array}$ & Vit b $\mid 2<200$ & $200<$ vit b | $2<350$ & Diabetes & $\begin{array}{l}\text { Hypo } \\
\text { glycemia }\end{array}$ & Impaired FBS \\
\hline 20 & 2 & 15 & 0 & 0 & 0 \\
\hline $100 \%$ & $10 \%$ & $75 \%$ & $0 \%$ & $0 \%$ & $0 \%$ \\
\hline $\begin{array}{l}\text { Total } \\
\text { participants }\end{array}$ & Anemia & Hypo calcemia & Hypothyroid & Without problem & $\begin{array}{l}\text { High } \\
\text { Cholesterol } \\
\text { or TG } \\
\text { blood level }\end{array}$ \\
\hline 20 & I & 0 & I & 2 & 0 \\
\hline $100 \%$ & $5 \%$ & $0 \%$ & $5 \%$ & $10 \%$ & $0 \%$ \\
\hline
\end{tabular}

Table 7 Severity of depression in total participants, and their needs according to the severity of their depression

\begin{tabular}{lllll}
\hline $\begin{array}{l}\text { Total } \\
\text { participant }\end{array}$ & $\begin{array}{l}\text { Mild } \\
\text { depression } \\
\text { Supportive } \\
\text { therapy }\end{array}$ & $\begin{array}{l}\text { Moderate depression } \\
\text { Refer to psychologist Doing } \\
\text { lab exam }\end{array}$ & $\begin{array}{l}\text { Moderately severe depression } \\
\text { Refer to psychiatrist } \\
\text { Doing } \\
\text { lab exam }\end{array}$ & $\begin{array}{l}\text { severe depression } \\
\text { Refer to psychiatrist, psychologist } \\
\text { Doing } \\
\text { lab exam }\end{array}$ \\
\hline 109 & 27 & 30 & 20 & 15 \\
$100 \%$ & $24.70 \%$ & $27.50 \%$ & $18.30 \%$ & $13.70 \%$ \\
\hline
\end{tabular}

Table 8 Severity of anxiety in total participants and their needs according to the severity of their anxiety

\begin{tabular}{lllll}
\hline $\begin{array}{l}\text { Total } \\
\text { participant }\end{array}$ & $\begin{array}{l}\text { Mild anxiety } \\
\text { Supportive } \\
\text { therapy }\end{array}$ & $\begin{array}{l}\text { Moderate } \\
\text { anxiety } \\
\text { Refer to psychologist Doing } \\
\text { lab exam }\end{array}$ & $\begin{array}{l}\text { Moderately severe anxiety } \\
\text { Refer to psychiatrist } \\
\text { Doing } \\
\text { lab exam }\end{array}$ & $\begin{array}{l}\text { severe } \\
\text { anxiety } \\
\text { Refer to psychiatrist, psychologist } \\
\text { Doing } \\
\text { lab exam }\end{array}$ \\
\hline 109 & 34 & 35 & 21 & 0 \\
$100 \%$ & $31.20 \%$ & $32.10 \%$ & $19.20 \%$ & $0 \%$ \\
\hline
\end{tabular}

All of the students that the system had recommended to be visited by a physician or a psychiatrist, have been visited, and got a credit for future visit, if necessary. They treated via using vitamin $\mathrm{D}$, vitamin b12, vitamin b2 for impaired fasting glucose, proper diet, no one treated by antidepressant or ant anxiety. After four month we came back to the high school to find out whether this system was effective in reducing depression or anxiety or not.

\section{The results after three month}

The participants divided to three groups

1. Group one: treated patients, ones who continue treatment during four month.
2. Group two: semi treated patients, ones who began the treatment but they not continue it for four month, they told us while they use what had prescribed they feel better.

3. Group three: no treated patients, ones who have not begun treatment during four month.

Statistical results of PHQ9 changes in treated patients between May and Oct 2014: it is significant with $P$ value $0.023<0.05$.

i. Statistical results of PHQ9 changes in non treated patients between May and Oct 2014: it is notsignificant. $(\mathrm{P}$ value $=0.331$ $>0.05$ ) 
ii. Statistical results of PHQ9 changes in semi treated patients between May and Oct 2014: it is not significant. $(\mathrm{P}$ value $=0.055$ $>0.05$ )

iii. Statistical results of GAD7 changes in treated patients between May and Oct 2014: it is not significant. $(\mathrm{P}$ value $=0.069>0.05)$ iv. Statistical results of GAD7 changes in non treated patients between May and Oct 2014: it is not significant. $(\mathrm{P}$ value $=0.103$ $>0.05)$

v. Statistical results of GAD7 changes in semi treated patients between May and Oct 2014: it is no significant.(GAD7 before and after treatment is equal)

Table 9 The rate of medical diseases in the persons, chosen by the system for lab exam

\begin{tabular}{llllll}
\hline $\begin{array}{l}\text { Impaired } \\
\begin{array}{l}\text { Fasting } \\
\text { Glucose }\end{array}\end{array}$ & $\begin{array}{l}\text { Hypo } \\
\text { glycemia }\end{array}$ & Diabetes & $\begin{array}{l}\text { I0< } \\
\text { Vitamin D } \\
<30\end{array}$ & $\begin{array}{l}\text { Vitamin D } \\
<10\end{array}$ & $\begin{array}{l}\text { Total } \\
\text { Participants }\end{array}$ \\
\hline 8 & & $\mathrm{I}$ & 33 & 4 & \\
$21 \%$ & $2.50 \%$ & $2.50 \%$ & $86.80 \%$ & $10.50 \%$ & $100 \%$ \\
\hline Normal & Hypo or & Anemia & $\mathbf{2 0 0 <}$ & Vitamin B I 2 & Total \\
& Hyper & & Vitamin B I 2< & $<200$ & Participants \\
& Thyroid & & 350 & & 38 \\
\hline 0 & 0 & 0 & 27 & 2 & $100 \%$ \\
\hline
\end{tabular}

\section{Conclusion}

a. By using this system: we can decrease the rate of depression without using any antidepressants.

b. We can create medical and psychiatrically profile for several people without direct attending physicians or psychiatrists.

c. We could saw there were different results in lab examinations in boys' high schools and girls' high schools. We need more practice with this system to can consider the best for each group.

\section{Acknowledgments}

None.

\section{Conflicts of interest}

Author declares there are no conflicts of interest.

\section{Funding}

None.

\section{References}

1. Sadock. Kaplan and Sadock's Synopsis of Psychiatry. (10th edn). 2007. p. 528.

2. Sadock. Kaplan and Sadock's Synopsis of Psychiatry. (10th edn). 2007. p.1259.

3. Sadock. Kaplan and Sadock's Synopsis of Psychiatry. (10th edn). 2007. p. 581.

4. Sadock. Kaplan and Sadock's Synopsis of Psychiatry. (10th edn). 2007. p. 1260 .

5. Sellers R1, Harold GT, Elam K, et al. Maternal depression and cooccurring antisocial behaviour: testing maternal hostility and warmth as mediators of risk for offspring psychopathology. J Child Psychol Psychiatry. 2014;55(2):112-120.

6. Sadock. Kaplan and Sadock's Synopsis of Psychiatry. (10th edn). 2007. p. 1220.

7. Merck manual. 18th edn. p. 1668 